\title{
KULTŪRINIO KONTEKSTO REIKŠMĖ VERTINANT ARCHITEKTÜRINI KOMPLEKSĄ
}

\author{
Vytautas Petrušonis \\ Architektūros pagrindu ir teorijos katedra, Vilniaus Gedimino technikos universitetas, \\ Pylimo g. 26/Trakug. 1, 01332 Vilnius, Lietuva \\ El.paštasvytas_petr@yahoo.com \\ Iteikta 20101126
}

Santrauka. Šiuo metu architektūriniai kompleksai iš esmès vertinami nepasitelkiant papildomos kontekstą paryškinančios informacijos arba kontekstas pristatomas ribotai, remiantis įdomesniais statiškai traktuojamais faktais apie sukūrimo laikotarpị, apie kūrẻjus, stilių. Manoma, jog kuo daugiau įdomesnių savybių, kurių svarba nekelia abejonių turintiems apibrèžtą kvalifikaciją, atskleidžiama, tuo objektas vertingesnis. Tačiau taip žiūrint neįvertinama tai, kad tikroji komplekso, jo dalių verte atsiskleidžia dinamiškai veikiant papildomai informacijai apie kultūrinius kodus, liudijančiai apie komplekso objektų sąsajas su kultūrinèmis idèjomis. Ši papildoma informacija, kuri pristato kultūrinius archetipus, figūruojančius ne „Aš‘, o „Mes“ plotmèje, aktualizuoja svarbias gilesniam objekto vertės suvokimui konotacijas. Nediferencijuotas visumos suvokimas vertinimo akto metu aktyvizuoja ikirefleksiniu suvokimu pagrịstos vaizdinių kalbos dešifravimą; tai procesas, analogiškas mįslès įminimui. Tokiomis sąlygomis vertintojui objekto vertė atsiskleidžia ne per „loginị“, o per „estetinị supratimą“. Papildomas tekstas, kurio struktūra galètų būti artima tezaurui, iš esmès pristatytų aktualius kultūrinių archetipų rinkinius, kurie, patekę ị vertintojo akiratị, leistų praplèsti kultūrinị kontekstą ir paskatintų adekvatesnị bei motyvuotesnị architektūrinio komplekso vertès suvokimą.

Lentvario dvaro parko ansamblio semantinès analizės pavyzdžiu parodoma, kaip praplètus kontekstą galima išsamiau atskleisti objektų kultūrinę vertę. Dabar šio parko kaip komplekso vertè apibrèžiama remiantis paviršutiniška istorine, kultūrine ir estetine informacija.

Reikšminiai žodžiai: architektūrinių kompleksų vertinimas, architektūros konceptinė interpretacija, kultūrinis kontekstas, vertinimo proceso psichologinis pagrindas, Lentvario dvaro parko semantikos bruožai.

\section{Ivadas}

Igyvendinto architektūrinio komplekso vertès nustatymas svarbus tolesnei paties komplekso būčiai. Nors architekto veikla natūraliai patenka tiek ị architektūrinès aplinkos plètros, tiek ir apsaugos veikimo sritis, daugiausia ji sietina su atstovavimu plètros interesams. Architekto pastangų inkorporavimas ị apsaugos sriț šiuo metu turi ribotas galimybes dèl to, kad informacija apie pertvarkomo objekto vertes struktūruojama ir ị projekto rengimo lauką îtraukiama neatsižvelgiant į kūrybos psichologijos ypatumus. Kaip matyti iš Vilniaus Sereikiškių parko atkūrimo problemų, kurias su nuoskauda aptaria Konstantinas Jakovlevas-Mateckis (2010), tai aktualu ir tokiems kompleksams kaip parkų ansambliai.
Tinkamas architektūrinio komplekso ypatumų pažinimas, jo ịvertinimas gali suteikti motyvuotą pagrindą jo vertès išsaugojimui. Autoriaus nuomone, svarstant kūrybinius klausimus ir vertinant veiklos rezultatus, plètros ir apsaugos subjektams susitarti tinkamas pamatas būtų architektūrinio komplekso, jo dalių verčių supratimas, atskleidžiant aktualias kultūrines idèjas (su kuriomis susiję komplekso elementai, pats kompleksas), pažistant jas.

Straipsnio tikslas pabrèžti kultūrinio konteksto reikšmę vertinant architektūrinį kompleksą. Tam iškeliami tokie uždaviniai: a) kritiškai aptarti šiuo metu vyraujančius teorinius meninès raiškos vertinimo modelius, 
parodant, jog būtent didesnis dèmesys kultūriniam kontekstui gali užtikrinti adekvatesnį architektūrinių kompleksų vertinimą; b) remiantis konkretaus architektūrinio komplekso - Lentvario parko - pavyzdžiu pademonstruoti vertinimo atsižvelgiant ị kultūrinị kontekstą privalumus; c) aptarti straipsnio teiginius praktinés veiklos orientavimo kontekste.

Nepaisant to, kad aptariant teorinius kultūrinio konteksto reikalus, bus nagrinèjamas parkas, kuriam labiau tiktu „meniškesnè“ ansamblio sąvoka, toliau bus vartojama „architektūrinio komplekso“ sąvoka. Ši sąvoka figūruoja kaip dalinis „ansamblio“ sinonimas. Tai tinka ir dvaro sodybos, ir parko kaip komplekso ansamblio atvejui (Дворцово-парковый комплекс 2010) ${ }^{1}$. Bendresnés komplekso sąvokos vartojimas (i ją įeina ir "urbanistinio komplekso" sąvoka) tikslingas metodologiniu požiūriu, nes straipsnyje keliami klausimai aktualūs bendrai visiems architektūriniams kompleksams.

\section{Kultūrinio konteksto reikšmė meninès raiškos analizèje}

Meninès raiškos analizė XX a. estetikoje, anot George Dickie (2005), perejo tris etapus, kurie atspindi apibrèžtus vertinimo principus, sąlygiškai vadinkime juos „vertinimo modeliais“: psichologinis, analitinis, kontekstinis. Pirmajame etape vertinimas buvo grindžiamas individo psichologijos ypatumais, antrajame etape buvo linkstama ị pozityviai atliekamą analizę. Trečiasis objekto meninès vertès traktavimo etapas pasižymi ypatingu konteksto pabrěžimu.

Analitinio estetikos raidos periodo atstovai estetines kategorijas, sąvokas, savybes aiškiai atriboja nuo „neestetinių“, pabrèždami išlavinto skonio, sugebèjimo suvokti, jautrumo reikšmę. Nors ir deklaruodami savo požiūrio skirtingumą nuo pirmojo - psichologinio etapo, analitinio periodo filosofai estetikos problemas taip pat bandè spręsti remdamiesi individo psichologija (Dickie 2005: 78).

Pastaraisiais dešimtmečiais vis didesnè reikšmè skiriama meno kūrinio kontekstui, suprantant ji plačiai, teigiant, kad meno kūrinio suvokejo mintị ir elgesị veikia ne tiek psichologiniai reiškiniai, kiek meno kūrinio kultūrinis kontekstas (Groat, Wang 2002: 136; Dickie 2005: 279; Eaton 2009). Susitelkiant vien ties estetine meno funkcija ir vengiant praktinių ir semantiniu kūrinio apibrěžčių, forma atskiriama nuo turinio ir būtent konteksto ịvertinimas gali padèti tokio atskyrimo

\footnotetext{
Šių sąvokų bendrumą pabrèžia ir lietuvių autorių parengtas Tarptautinių žodžių žodynas: „ansamblis: harmoninga visuma vientisos architektūrinès kompozicijos ir stiliaus statinių bei irrenginių kompleksas" (Kvietkauskas 1985: 34).
}

išvengti; nurodoma, jog kontekstas yra neišardoma kūrinio struktūros dalis, meno kūrinị reikia matyti jo kontekste, o ne vien tik atsižvelgiant ị menininko oeuvre ar stiliaus raidą (Belting ir kt. 2002: 227, 238).

Deja, nepaisant teorinių darbų, pagrindžiančių kultūrinio konteksto įvertinimo svarbą, architektūriniai kompleksai šiuo metu vertinami nepasitelkiant papildomos kontekstą paryškinančios informacijos. Tai liudija apie individo psichologija apsiribojantị vertinimą, ignoruojant tai, jog tikroji komplekso vertè atsiskleidžia per suvokimą, kurị stimuliuoja prieštaringų, sunkiai diferencijuojamų reikšminių faktų îvairovė, jie nepaklūsta loginèms formuluotèms. Vertinimo akto metu svarbu atsižvelgti ị žinių tinkliškumą, ị tai, kad žinios dažnai sudètos viena ị kitą ir negali būti iš karto suvoktos, kol nesuveike atitinkamas stimulas. Vertei nustatyti (ji faktiškai nustatoma ikirefleksiniame suvokimo etape), ypač svarbus orientuojančios papildomos „,išorinès" informacijos apie kultūrinių idejjų raišką nagrinèjamame komplekse vaidmuo. Tokia informacija, kuri iš tikrųų yra archetipine kultūrinè ir figūruoja ne „Aš", o „Mes“ sąmonès lauke, atsiskleidžia holistinio pobūdžio vaizdinių poveikio suvokejui metu; būtent ji aktualizuoja svarbias išsamesniam objekto vertès suvokimui konotacijas ir itin praplečia kultūrinį kontekstą.

Nediferencijuotas visumos suvokimas aktyvizuoja ikirefleksiniu suvokimu pagrịstos vaizdinių kalbos dešifravimą, tai procesas, analogiškas mịslès įminimui. Šiame procese i̇minimo procesą „orientuoja“ būtent papildoma išorinè informacija - tai, kas regima, žinoma ir prisimenama vertinimo akto metu. Tokiu atveju objekto verte atsiveria ne per loginị suvokimą, bet per vadinamajji ,estetinị supratimą “ (Petrušonis 2008). Tokị procesą užtikrina atodaira ị papildomą informaciją apie kultūrinių idèjų raišką komplekse. Tokia informacija galètų būti pateikta specialiu tekstu, kurio struktūra gali būti artima dinaminiam semantiniui žodynui - tezaurui, kuris yra puiki priemonè kompaktiškai pateikti vertinimui reikalingus duomenis, taip pat skatinti kūrybini procesą - orientuojant, katalizuojant kūrybinę mintị (Petrušonis 2002).

Šiuo metu vis daugiau demesio semantikai, kultūrinèms idejjoms skiriama ir Lietuvos architektūros tyrinètojų darbuose. Audrius Novickas savo studijoje apie miestų aikštes, remdamasis kitų autorių mintimis ir savo įžvalgomis, dèsto, jog pastaruoju metu vis labiau užsimenama apie meno ir gyvenimo neatskiriamumą, apie tai, kad viešojoje erdveje besiskleidžiantis meninis tekstas yra atviras, jis formuoja patyrimo aplinką (Novickas 2010: 55-57). İdomu tai, kad šios 


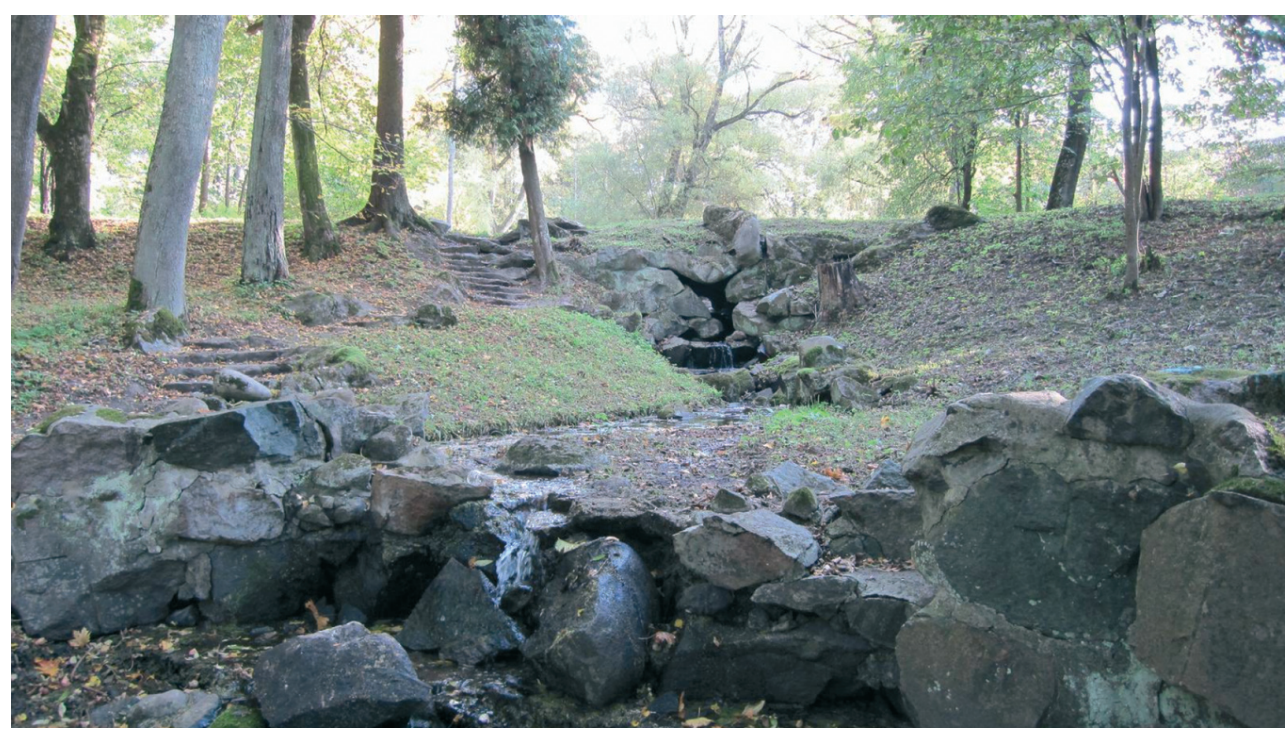

1 pav. Charakteringas Lentvario parko fragmentas. Dirbtinių uolų kaskados

Fig. 1. Characteristic fragment of Lentvaris Park. Artificial rocks, cascades

"naujovès“ rezonuoja su archajinio pasaulio aplinkos kūrimo idèjomis².

Kultūros kategorijos ${ }^{3}$ žymi visuomenès ir individo gyvenimui svarbias kokybines būsenas, glaudžiai susijusias su „amžinomis“ kultūrinèmis idejomis (pasižyminčiomis metafiziniu pobūdžiu), aktualizuojamomis per realaus pasaulio fizinius objektus. Tinkamas kultūrinių idejų aktualizavimas veikiant architektūrinio komplekso fizinès būties plotmèje (tvarkant esamus architektūrinius kompleksus, rengiant naujus projektus) gali leisti toms kokybinèms būsenoms atsiskleisti ir veikti suvokejo sąmonę nepriklausomai nuo laikotarpio.

\section{Lentvario parko kultūrinis kontekstas}

Diskusijos dèl Sereikiškių parko tvarkymo, planai atnaujinti Eduardo Fransua Andre (1840-1911) parkus (Dobkevičius 2004) paskatino autorių skirti dèmesį vienam iš įdomiausių šio kraštovaizdžio architektų kūrinių - Lentvario parkui (charakteringą parko fragmentą

\footnotetext{
2 Šiuo požiūriu aktualios Vladimiro Toporovo mintys apie moderniausių kosmologinių modelių glaudžias sąsajas su archajinèmis kosmogonijomis (Топоров 1983), apie ilgalaikị kultūros vertybių pobūdị (Топоров 1973).

${ }^{3}$ I t kultūros lauką, siekiant išlaisvinti meno reiškinių ịprasminimą iš būties plotmès, iš laiko vergijos (Бахтин 1986), būtina žvelgti per susijusių su tapsmo plotme kultūros kategoriju prizmę. Kultūros kategorijų vaidmuo reprezentuojant istorinio pažinimo modelius turi ypatingą reikšmę. Tai, remdamasis prancūzų istorikų Analų mokyklos atstovų darbais, nuodugniai atskleidè Aronas Gurevičius (1989).
}

žr. 1 pav $)^{4}$, sukurtam XIX a. pabaigoje dvaro savininko grafo Vladislavo Tiškevičiaus užsakymu ${ }^{5}$.

Deja, pasigilinus $\dot{i}$ atliktus parko tyrimus (Tauras 1989; Levandauskas 1989, 2000; Lentvario dvaro sodybos parkas 1996; Deveikiené, Deveikis 2000, 2010; Stučkaitè 2000; Apžvalginè ir situacijos... 2001; Šetkus 2002; André-Olivier, Deveikienè, Deveikis 2006; Deveikis 2010; Lentvario parkas 2010) ${ }^{6}$, tenka daryti išvadą, jog visi tyrimai iš esmès skirti tik parko kūrèjo asmenybei, jo veiklai (oeuvre) ir parko stilistikai, pabrèžiant bendrinius momentus, iš esmès mažai susijusius su pačiu parku, nagrinèti. Visuose parkui skirtuose tekstuose turinys faktiškai atskirtas nuo formos.

Glaustam parko apibūdinimui pasinaudosime tinklapyje „Mano parkas“ pateikta refleksija: „Peizažinè Lentvario parko dalis neabejotinai yra viena iš įdomiausių Lietuvoje. Andrè čia sukūrè „kalnų parką“ - parką su uolų masyvais, kalnų tiltais, uoletomis ar akmenuotomis upelių ir tvenkinių pakrantemis, vingiuotais takais su daugybe akmeninių laiptelių. Siekiant sustiprinti kuriamo kalnų peizažo įspūdị, buvo remtasi augalų gamtinio zoniškumo kalnuose principu - žemesnèse

\footnotetext{
${ }^{4}$ Nuotraukos 1, 2, 4-6 paveiksluose - Vytauto Petrušonio (2010 m. spalis).

${ }^{5}$ Už pažintị su šiuo nuostabiu parku autorius yra dekingas kolegai Vytautui Levandauskui, kuris prieš keletą dešimtmečių būtent jame parinko pèsčiųjų žygio pradžią.

${ }^{6}$ Lentvario parkas nagrinètas dviejuose autoriui žinomuose baigiamuosiuose darbuose (Stučkaitè 2000; Šetkus 2002). Abu darbai skirti stilistinei ir kompozicinei analizei, juose gvildenama iš esmès tik būties plotmè.
} 
vietose vyravo lapuočiai, o aukštesnèse spygliuočiai“ (Lentvario parkas 2010).

Labai gražus parkas (kurio didesnioji dalis peizažinio stiliaus, geometrinis parteris suplanuotas prieš rūmus), šio straipsnio autoriaus manymu, dar nèra pakankamai ištirtas. Lentvario parko kaip kultūros vertybès aprašas yra parengtas ignoruojant kultūrinį kontekstą: „Kalvelès šlaitai ir kaskadinio upokšnio krantai kai kur sutvirtinti stambiais akmens luitais bei akmenimis, plastiškai sujungtais betonu, imituojant natūralią uolą. Taip pat padarytos ir akmeninių laiptelių grupès, įrengtos takų staigesnio nuolydžio ruožuose. Unikali pasivaikščiojimo takų kompozicija. Jie vingiuoja, raitosi kaskadinio upelio šlaitais, kyla ir leidžiasi nuo kalvų, ant kurių stovèjo įvairios skulptūros. Šiuo metu išlikusi tik kolona, ant kurios stovejo Tado Kosciuškos biustas. Nuo takų atsiveria gražūs vaizdai, įdomios perspektyvos. Parko i̇domybe yra tiltas-viadukas per kaskadinị upokšnị ir greta vingiuojantị taką. Jo skliautai atrodo tarsi iškalti natūralioje uoloje. Vakarinèje sodybos dalyje, parko pakraščiu teka bevardis upokšnis, kai kuriuose istoriniuose šaltiniuose įvardintas kaip kanalas. Upokšnis per sukrautą iš stambių akmenų krioklį ịkrinta ị ežerą" (Lentvario dvaro... 1996). Visi vertingieji parko bruožai apibrežziami remiantis paviršutiniška istorine, kultūrine ir estetine informacija.

Semantiniu požiūriu parkas iki šiol nebuvo tirtas. Kokių nors koncepcinio pobūdžio aiškinimų, susijusių su kultūrinèmis idèjomis, nuorodų ị kultūrines prasmes, kurias būtų pateikęs pats Andrè, taip pat kol kas aptikti nepavyko?.

Apsiribojant peizažine parko dalimi, bus aptarti kai kurie parko semantiniai bruožai. Bus išskirti su Žemés rojaus ${ }^{8}$ kultūrine idejja susiję objektai: obeliskas, tiltas-viadukas su grota, krioklys, „filosofų alejja“. Visu šiu objektų (paskutinis net neidentifikuotas) kultūrinè reikšmè iki šiol nebuvo aptarinejjama. Autorius, prisiimdamas atsakomybę, pabrěžia obelisko ir „filosofų alejos“ svarbą (pastarasis objektas su Žemés rojaus idejja susijęs iš dalies).

Kas pirmiausia atejus ị parką krenta ị akis, tai „kalnų“ vaizdai. Tai pabrèžia ir kiti tyrinètojai: „Lentvario parke daugiausia, palyginti su kitais Andre kurtais parkais Lietuvoje, „kalnų vaizdų“ - dirbtiniai grotai, kriokliai, akmenimis įreminti upelių krantai ir takai

\footnotetext{
${ }^{7}$ Lietuvių kalba prieinami tik Andrè knygos L"art des jardins: traité général de la composition des parcs et jardins („Sodų menas: traktatas apie parkų ir sodụ kūrimą") (Andre 1879a) fragmentai (Andre 1879b, Andre 1879c). Tai patarimai, kaip estetiškai komponuoti įvairius elementus.

8 Žemés rojaus idejos populiarumą XVII a. landšaftinèje architektūroje aptaria Michailas Jampolskis (Ямпольский 1987: 27). Taip pat Žemés rojaus temai atskleisti pasinaudosime Eugenio Lo Sordo darbu (2004).
}

palei juos, vingūs takai šlaituose, apžvalgos kalnelis su įsisukančiais laiptais, dirbtinès uolos" (Deveikienè, Deveikis 2000).

Pradèkime nuo objekto, kurị sąlygiškai šio straipsnio autorius pavadino obelisku (2 pav.). Kai kur nurodoma, kad parke buvo „kolona, ant kurios stovèjo Tado Kosčiuškos biustas", tačiau tiksli vieta nepateikiama (Lentvario dvaro... 1996). Kaip nurodo Hans Biedermann (2002: 204), kolona tam tikrais atvejais gali būti tapatinama su obelisku. Dèl savo vertikalumo abu šie objektai vienodu laipsniu sietini su saulès kultu, su dieviškąja šviesa. Šios konotacijos ypač svarbios Žemés rojaus kontekste. Beje, net ir sąsaja su herojiška Kosčiuškos asmenybe, kuri gali būti priskiriama Pirmtakams, dieviškosios šviesos nešejams, tam neprieštarauja (Petrušonis 2004).

Padarykime ekskursą ị šalį. Romoje, Navona aikštejje, stovi Gianlorenzo Berninio „Keturių upių fontanas" (pastatytas 1651 m.) (3 pav.). Fontane matomas egiptietiškas obeliskas, pastatytas ant uolos, iš kurios urvų - grotų - išteka keturios rojaus upès. Idejja pasiskolinta iš jėzuito Atanasijaus Kircherio koncepcijos (Ямпольский 1987: 27). Anot Kircherio9, veikiant dieviškajai šviesai, krintančiai ant pirmapradžio chaoso, kuri Łikūnija uolos, gimsta šventos upès.

Eugenio Lo Sardo nurodo, jog Berninio „Keturių upių fontane" saulę simbolizuojantis obeliskas yra pastatytas ant uolų (ịkūnijančių bažnyčią) virš urvų (simbolizuojančių instinktus, nuodèmes), iš kurių išteka keturios svarbiausios pasaulio upès (tuo metu buvo žinomi tik keturi žemynai - Australija dar buvo neatrasta; keturios upès - tai Nilas, Rio de la Plata, Dunojus, Gangas). Berninio fontanas gali būti skaitomas kaip Žemés rojaus vaizdinys; kartu tai buvo katalikybès sklidimo per keturis žemynus vaizdinys. Fontane politinè programa - „Dvasinè popiežiaus viršenybe $e^{\text {“ }}$ - paversta meno šedevru (Lo Sordo 2004: 55).

Dabar grịžkime i parką. Šio straipsnio autoriaus manymu, ten išreikšta būtent Žemès rojaus tema. Tačiau ji pristatyta netiesiogiai, per kultūrinę parkų kūrimo tradiciją, kuri, be abejo, buvo paveikta Berninio ir Kircherio „modelio“. Pagrindine tokio aiškinimo priežastis tai kalnuoto, uolèto peizažo sukūrimas ir kolonos-obelisko buvimas ant kalvos. Nepaisant šio elemento atsiradimo parke aplinkybių (ir to, ar tai buvo tik pagrindas Tado Kosciuškos biustui, ar ne), svarbiausia tai, kad šis elementas reprezentuoja Žemes rojaus idejjai reikšmingą aktantą. Gaila, kad nieko

\footnotetext{
${ }^{9}$ Keletas žodžių apie Kircherị. Teigiama, kad tai paskutinis universalas prieš prasidedant Naujiesiems amžiams. Jo reikšmę kultūriniu studiju kontekste liudija neseniai pasirodžiusi Paulos Findlen sudaryta knyga Athanasius Kircher. The Last Man Who Knew Everything (2004).
} 

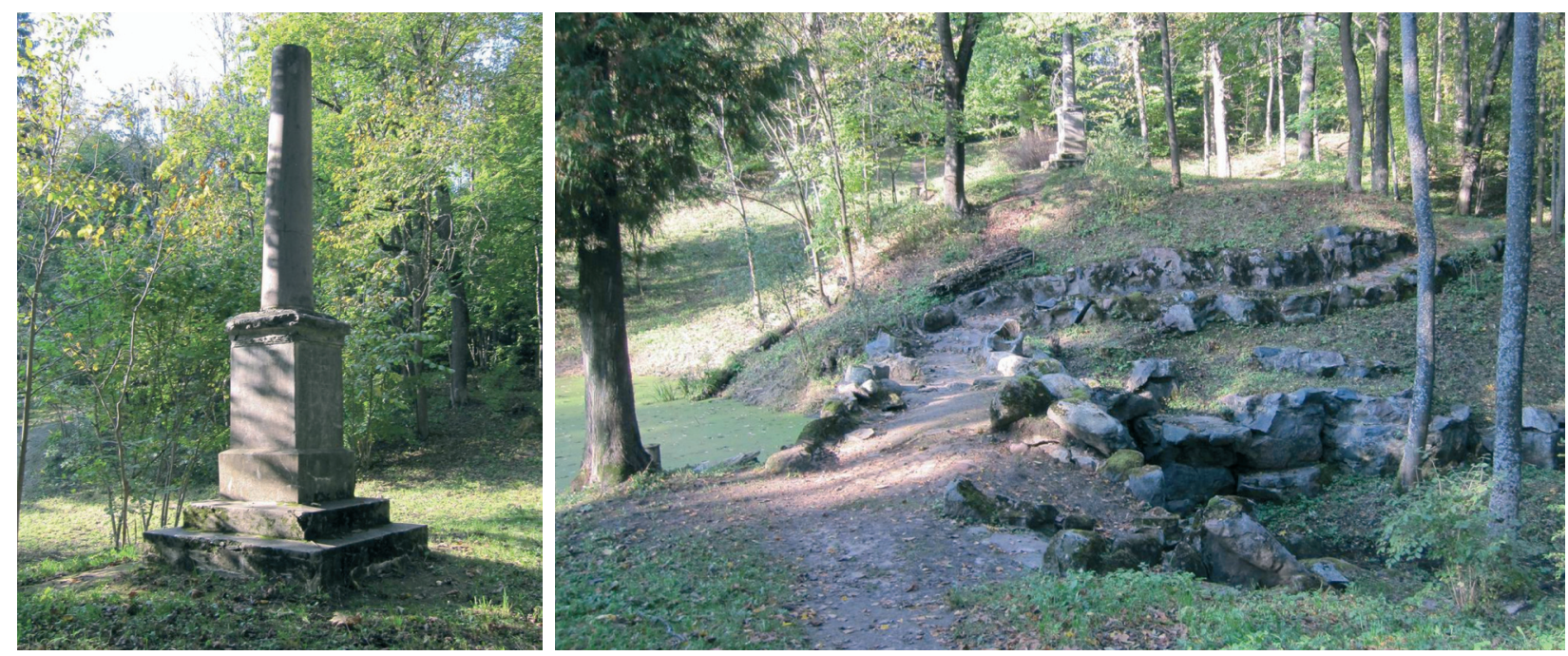

2 pav. Lentvario parko obeliskas

Fig. 2. "Obelisk" of Lentvaris Park

nežinome apie kitas skulptūras, buvusias parke, net negalime spèlioti, kokie buvo galimi jų semantiniai sąryšiai.

Lentvario parkas kurtas istorizmo dvasia, tad naturalu, jog jame atsispindi ir baroko (kaip ir sentimentalizmo, romantizmo) kraštovaizdžio architektūros patirtis. Nagrinejjamos temos kontekste parke atliktos meninès ivvairių stilių sintezès atžvilgiu reikšminga ši E. Andrè mintis: „Grožis yra aktyvi jèga amžinoms idejoms realizuoti“"(Brunzaitè-Baltrus 1997: 82).

Matyti, kad parke figūruoja ir upès, ir uolos, ir urvai (grota - po tiltu-viaduku). Jie apeinami vingiuotais pasivaikščiojimo takais. Berninio fontane „kieti“ elementai yra sukoncentruoti ị kompaktišką vienetą, parke jie tarsi išsiskaido - kalvos, uolos, urvai pristatomi decentralizuotai, tačiau tai yra tapatu Žemes rojaus idejjai dèl aktyvaus konotacinio turinio. Taip pat dispersiškai aplinkoje pasklidęs ir „vanduo“ - „rojaus upių“ užuominos: upeliai, šaltiniai, kaskados, tvenkiniai. Sujungianti šiuos elementus takų sistema primena labirintą. Nors parke upès išteka ne konkrečiai iš po tos kalvos („uolos“), ant kurios stovi obeliskas, suvokèjui dèl topologinių vaizdinių kodo ypatybių tai izomorfiška „ištekejimo iš po uolos" situacijai ${ }^{10}$.

Vaikštant takų labirintu prieinama prie kaskadų, tvenkinių - visa tai figūruoja kaip gąsdinanti, o kartu ir adepto (kuriam pasivaikščiojimas po parką yra piligri-

\footnotetext{
${ }^{10}$ Mitologinès erdvès, kurioje operuojama tik vaizdiniais, pobūdis yra „skiautinis“: erdvè ịsivaizduojama ne kaip kontinuumas, kuriam būdingi tam tikri požymiai, o kaip atskirų objektų visuma; tarpuose tarp jų erdvè tarsi nutrūksta (Lotmanas, Uspenskis 2004: 236).
}

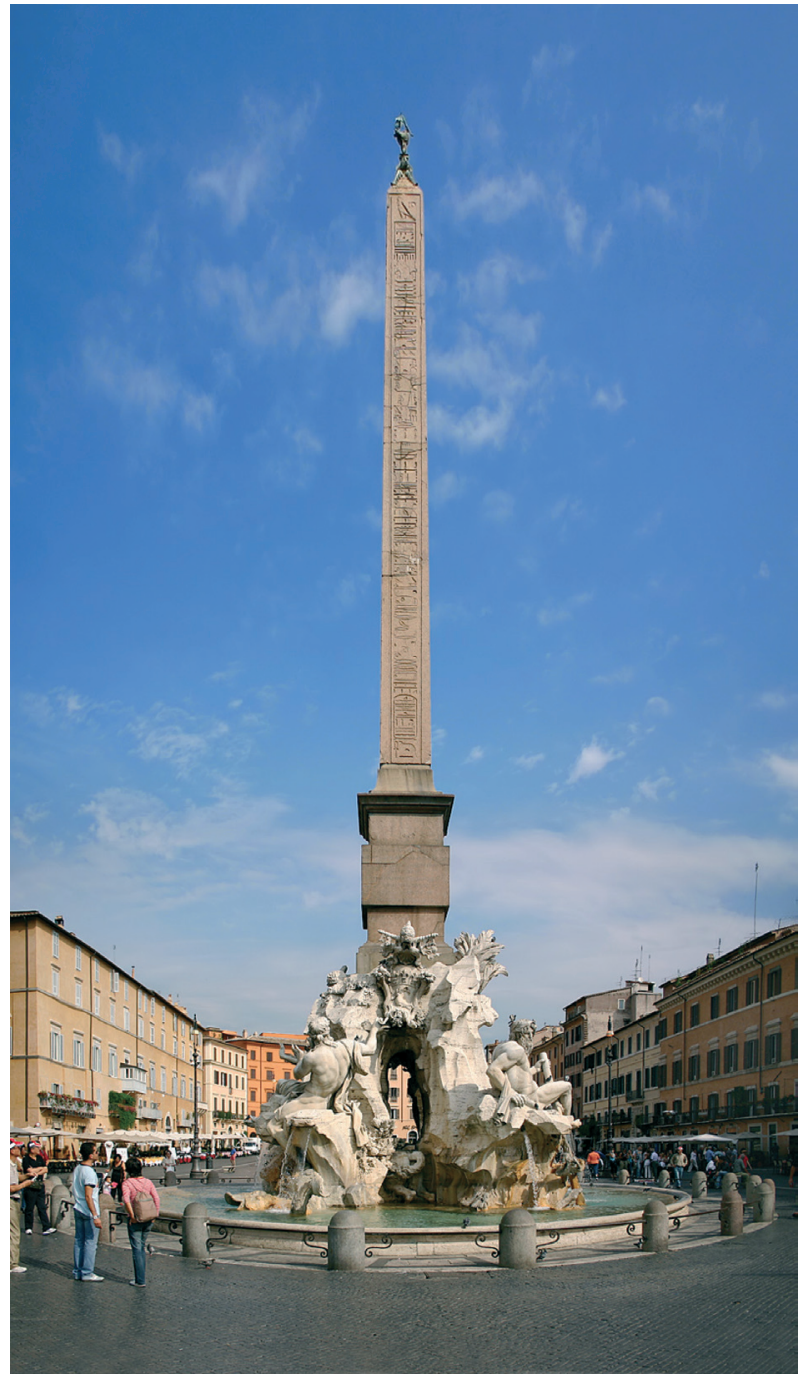

3 pav. Gianlorenzo Berninio "Keturių upių fontanas" Romoje, Navona aikštèje (1651 m.) (nuotraukos šaltinis - Fontana dei Quattro Fiumi (2005))

Fig. 3. Gianlorenzo Bernini "Fountain of Four Rivers" in Rome, Piazza Navona (1651) 


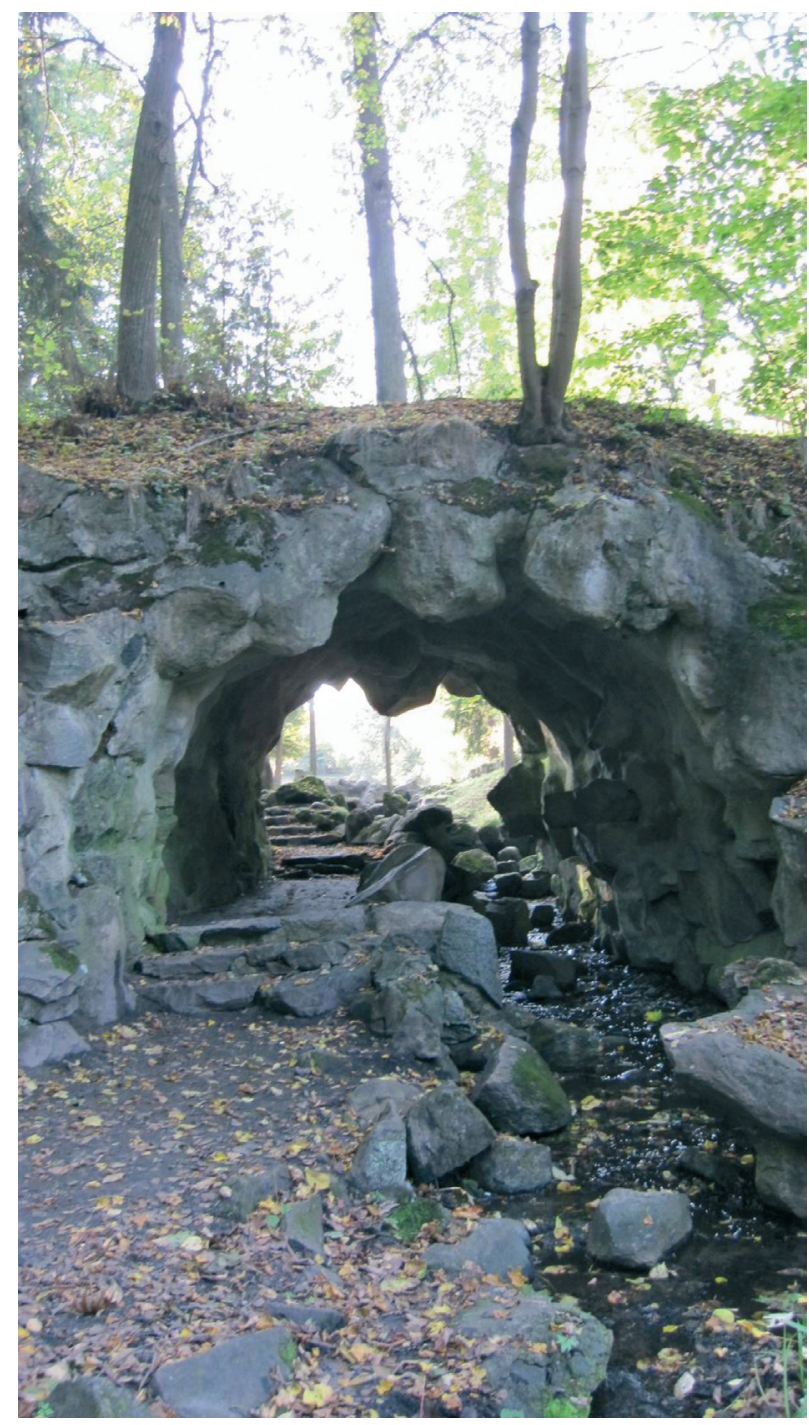

4 pav. Tiltas-viadukas su grota Lentvario parke

Fig. 4. Bridge-viaduct with grotto in Lentvaris Park

mystès dalis $\left.{ }^{11}\right)$ meditacinio ritualo dvasinio apvalymo priemonè (Ямпольский 1987: 33) ${ }^{12}$. Tokios kelionès metu tarsi ieškoma parke Nilo ištakų. Žinomas aiškinimas (ypač paplitęs XVII a.), kad pasiekti Nilo ištakas (kurios Afrikoje paslèptos slenksčiu, kaskadų masyve) tai tolygu suprasti magiškas gyvenimo paslaptis - suprasti pirminę, pirmapradę kalbą, pasiekti pirmykštę būseną, kuri apibūdinama visažinyste (Ямпольский

\footnotetext{
${ }^{11}$ Benediktas Andersonas nurodo piligrimystès svarbą asmenybès kultūrinès sąmonès formavimui, saviidentifikavimo procesams (Andersonas 1999).

${ }^{12}$ Kiti gąsdinantys parko objektai - pačios kalvos. Mitologiškai kalvų buvimas nuo seno siejimas su nuodèmingumu (pradžioje žemè buvo idealiai apvali). Kalnų atsiradimas tarsi liudija žemės degradaciją; tai ryškiausia Adomo ir Ievos nuodemès pasekmé; tad rojus, kuriame yra kalnai, ambivalentiškas, bauginantis, skatina apmąstymus (Ямпольский 1987: 30).
}

1987: 28). O tai, savaime aišku, yra piligrimo - atsinaujinimo ritualo adepto - siekiamybè.

Dabar pereiname prie kito su piligrimyste susijusio objekto. Tai tiltas-viadukas su grota (4 pav.). Jis minimas kone visuose parko aprašymuose, tačiau visai nekomentuojamas. Būties metafizinès hierarchijos skirtingos pakopos ypač gerai matomos šiame objekte. Du lygmenys pristatomi dviem persikryžiuojančiais keliais. Viršutinis lygmuo - šviesos ir gryno dvasingumo karalystè. Apačioje - žemai prieblandoje Egiptas (biblinè konotacija). Per urvą paprastai aktualizuojama švento perlo tema (Аверинцев 1987: 27). Būtent apačioje - urve - Lentvario parko grotoje yra ikalintas šventasis perlas. Po sunkios kelionès per kalvas uolètais takais (o kas sakè, kad dvasingumo ieškojimas lengvas?) nusileidžiama ị grotą, kurioje teka ir upokšnis, paskui su laimikiu - perlu - grịžtama ị tèvų namus, $\mathfrak{i}$ tèviškę. Tai akivaizdžiai siejasi su meditacine kelione. Paslapčių sužinojimas, ieškant upès ištakų, tapatus perlo - šventenybės - suradimui. Ieškoma tamsoje, prieblandoje, veikiant instinktams, nuodemingumo akivaizdoje (būtent su tuo urvą siejo A. Kircheris).

Kitas Lentvario parke figūruojantis Žemès rojaus aktantas - krioklys (5 pav.). Identifikacijai su dvasinemis vertybèmis ypatingą reikšmę turi krioklio, kuris nuo romantizmo laikų traktuotas kaip dievybès buvimo vieta (Ямпольский 1987), vaidmuo. Anot M. Jampolskio, vandens krioklys - tai tarpsemiotinio perkodavimo metafora, suvokiama kaip dvasinio prašviesèjimo proceso pristatymas. Šiuo požiūriu krioklio lankymas analogiškas kelionei prie Nilo ištakų. Būnant prie jo užslopinama sąmonè (krioklys, užgožiantis visus pojūčius, figūruoja kaip „derinys to, kas nesuderinama“), pasiekiamas pirmykštis suvokimo lygis, kuriame mąstoma vaizdiniais, pradedama aplinką suvokti kaip paslaptingų rašmenų tekstą, identifikuojamasi su tuo, kas gerbiama, kas ypač reikšminga (Ямпольский 1987).

Dabar pats rizikingiausias šio rašinio epizodas: „filosofų alejja". Su Žemés rojumi tai siejasi netiesiogiai, per meditacini piligrimystès kontekstą. „Piligrimui“ vaikštant po parką ypač svarbi lankytojo bendravimo su kultūriniais herojais, pirmtakais tema. Jau anksčiau buvo minèta Pirmtako svarba asmenybės socializacijai (Petrušonis 2004). Šiuo požiūriu įdomūs XVIII a. parku planuotojo Christiano C. L. Hirschfeldo traktate pateikiami siūlymai statyti parkuose įžymių žmonių paminklus kaip simbolinius ir kartu dekoratyvinius elementus (Bialostocki 1982: 440). Kalbèdamas apie melancholinių, meditacijai palankių parkų kurimo meną J. Bialostockis mini parko skulptūrų, paminklų (kenotafų) filosofams paplitimą. Pavyzdžiui, filosofo Jean-Jacques Rousseau antkapinis paminklas 

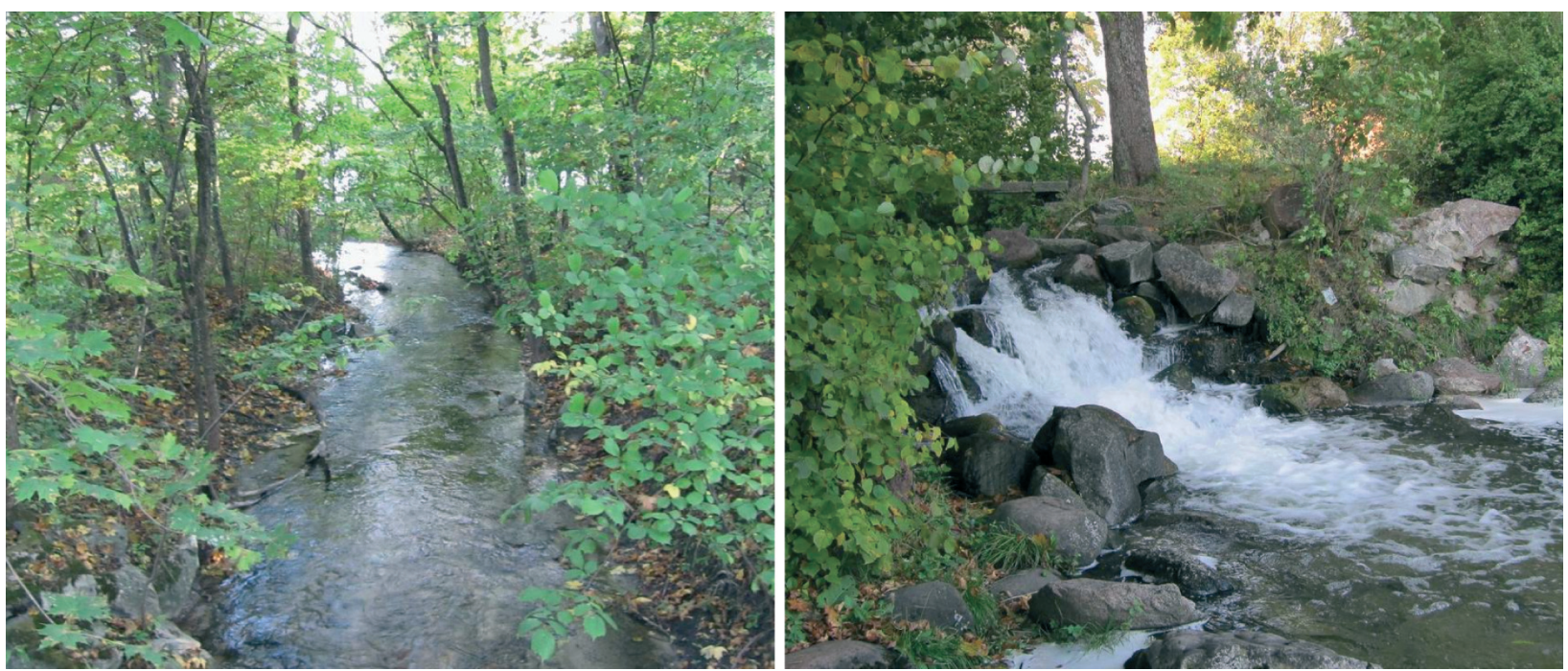

5 pav. Lentvario parko krioklys (kairèje upokšnis, virstantis kriokliu - dešineje)

Fig. 5. Waterfall in Lentvaris Park (its rivulet on the left)

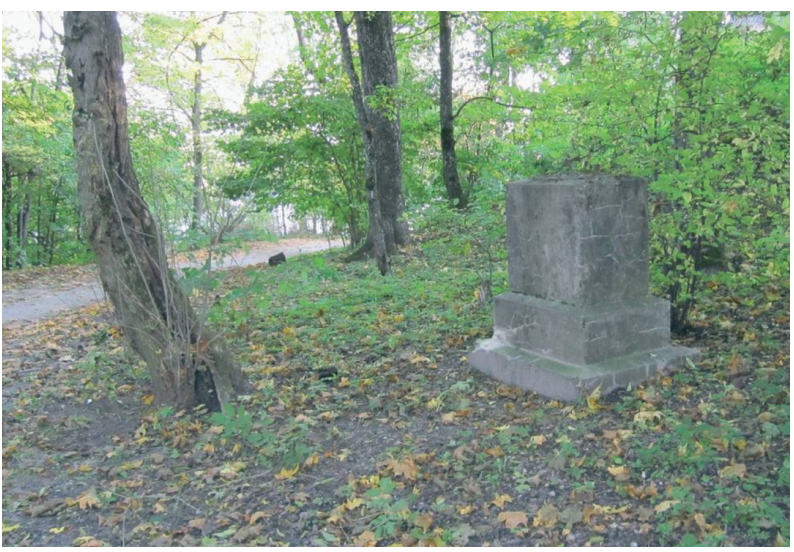

6 pav. Lentvario parkas. Postamentas "filosofo" (ar Pirmtako?) statulai. Kairejje toliau už keliuko - krioklys

Fig. 6. Lentvaris Park. Pedestal for "philosopher" or "precursor" statue? Waterfall is located on the left behind the path

buvo tiražuotas daugelyje sentimentalistinių parkų (Bialostocki 1982: 438). Fiktyvius ižzmių žmonių antkapius buvo ịprasta slèpti parko tankmèje, tarp jaunų atžalynų. Ypač buvo stengiamasi, kad būtų girdimas netoliese per slenksčius, kaskadas tekančio vandens šnaresys. Visa tai liudija melancholinių parkų ir kapinių bendrumą.

Lentvario parke, prie keliuko, pro krioklį vedančio ị prie ežero esantị paviljoną („Rivjera“), yra du objektai, panašūs ị statulų postamentus (vienos atvaizdas matyti 6 pav.).

Nors nèra jokių duomenų, tikètina, kad galbūt ant ju stovejo kokios nors statulos (tegul ir ne filosofų ar jžymiu žmonių, tegul kokiu nors mitologiniu ar literatūrinių personažų), aktualizuojančios tam tikras kultūrines idè- jas, kurios su visais laikais patrauklia Žemès rojaus idèja galëjo turèti tam tikrą ryši.

\section{Rezultatu aptarimas}

Taigi Lentvario parke reiškiasi kultūrinès idèjos, apie kurias nei parko tyrejjai, nei saugotojai ar galimi restauratoriai nieko nežino. Viena tokių tai reikšminga Europos kultūros istorijai Žemés rojaus ideja. Dalis parko objektų visai neidentifikuota, nežinoma šiame kontekste. Šios naujos žinios gali būti naudingos keleriopai.

Pirmiausia - rengiant restauracijos projektą - takai, upokšniai, tvenkiniai, augmenija, dirbtinès uolos ir pan., nepasinaudojus tokiomis žiniomis, gali būti nekorektiškai transformuojami. Kita vertus toks žinojimas gali turèti įtakos tvarkymo darbams ir itin apriboti galimas ,inovacijas“.

Architektūrinių kompleksų tyrimuose būtina suartinti formą ir turinị, nes tyrimai, gvildenantys vien formos, stiliaus, autorių asmenybès niuansus, yra tik atskira dalis - tik parengiamoji, tik büties plotmejje figūruojanti kultūros tyrimų dalis; tai kultūra siaurąja prasme; kultūra plačiąja prasme reiškiasi tik ten, kur atskleidžiami tapsmo ypatumai. Tai meno kūrinio itprasminimas kultūrinių idèjų fone.

Kitas svarbus aspektas - estetiniai išgyvenimai. Tam, kas žino apie parke ịkūnytas kultūrines idejas, bus daugiau peno estetiniams išgyvenimams. Tai susiję su estetinès patirties atvirumu, kai konotacijos sužadina ikirefleksinį - daugiamatị su komplekso aplinka susijusių vaizdinių struktūros suvokimą ir skatina estetikoje žinomą katarsị (apsivalymą). 
Tai natūraliai vyksta, kai stebintis kompleksą subjektas jau iš anksčiau yra igijęs papildomų žinių, kurios modifikuoja jo vertybių modelị. Neturintiems tokių žinių, bet savo veikla galintiems turèti įtakos parko elementų išlikimui ar jų transformacijai, o kartu ir kultūrinių i̇dèjų spektro modifikacijai minètos žinios turi būti prieinamos eksplicitiškai - išorinio teksto pavidalu. Geriausia tokiam orientuojančiam apmąstymus, vertinimus tekstui būtu panaudoti dinaminio semantinio žodyno - tezauro - schemą. Tokia kontekstą atskleidžianti papildoma informacija apie aktualias ansamblio elementų konotacijas, kultūrines idejjas, jų tarpusavio sąsajas gali padèti suvokti ansamblio visumos ir jo elementų gilesnę kultūrinę reikšmę. Šie duomenys, papildydami ir kontekstiškai Ł̣prasmindami dabartinius vertingụjų savybių aprašus, iš esmès esančius „objektiniais pasais“, galètų atlikti „subjektinio paso" funkciją ${ }^{13}$.

\section{Išvados}

1. Kaip rodo Lentvario parko tyrinëjimų analizè, vertinant architektūrinius kompleksus šiuo metu vyrauja individo psichologija grịsti estetiniai, analitiniai vertinimai, daugiau atspindintys specialistų erudiciją kaupiant ir apibendrinant meno stilių istorinę raidą atskleidžiančius faktus negu kultūrinę komplekso, jo elementų vertę.

2. Tokio tipo tyrimai neidentifikuoja meniniame turinyje atspindimų kultūrinių idèjų, kurios galètų atskleisti architektūrinio komplekso kultūrinị kontekstą. Tai pasenusiais meninès raiškos analizès principais (apsiribojančiais individo psichologija ir ignoruojančiais kolektyvinès sąmonès lygmenį) grindžiamos formos ir turinio atskyrimo nuostatos veikimo pasekmè, blokuojanti kultūrinių idejjų, ikūnytų architektūriniame komplekse, pažinimą.

3. Neturint kultūrinị kontekstą atskleidžiančios informacijos, architektūrinių kompleksų, jų elementų vertès nustatymas, o kartu ir praktinė veikla, susijusi su architektūrinių kompleksų tvarkymu (saugojimu, restauravimu ir pan.), pasižymi fundamentaliais trūkumais.

4. Vertinant architektūrinius kompleksus, į paveldo saugotojų, restauratorių kūrybinès veiklos lauką, greta šiuo metu kultivuojamų duomenų masyvų apie intuityviai ịvardijamas estetines, kultūrines ypatybes, būtina ịtraukti per papildomus tyrimus gautą infor-

\footnotetext{
${ }^{13}$ Apie vietovei rengiamo „subjektinio paso“ struktūrą jau buvo rašyta anksčiau (Petrušonis 2006). Ten taip pat pateikta Nekilnojamųjų kultūros vertybių vertinimo ir atrankos kriterijų aprašo (2005), kurio nuostatos blokuoja kultūrinio konteksto atskleidimą, kritika. Įvertinant sąsajas su kultūrinèmis idejjomis jau anksčiau buvo aprašyta Kauno Vienybės aikštė (Petrušonis 2004).
}

maciją apie komplekso elementų sąryšius su kultūrinèmis idejjomis ir taip užtikrinti kultūrinio konteksto įtraukimą ì praktinių problemų sprendimo lauką.

5. Kultūrines idejjas architektūriniame komplekse išreiškia fiziškai ir kognityviai esančių objektų konfigūracijos. Tokie lengvai atpažįstamų objektų ar jų denotacinių reikšmių ryšiai su kultūrinèmis idèjomis aktualizuoja, pristato sociokultūriškai reikšmingas kokybines būsenas (aktualias religiniu, politiniu, edukaciniu požiūriais).

6. Aktualizuojant kokybines būsenas dalyvaujančios konotacijos (ryšiai su kultūrinèmis idejomis) atlieka kultūrinių kodų, iš esmès formuojančių individualią architektūrinio komplekso semantinę sistemą, funkciją.

7. Siekiant pristatyti architektūrinių kompleksų vertę, kultūrinị turinị, reikia kiekvienam kompleksui parengti dinaminị sisteminị jo semantinès struktūros modelį, kuris greta objektinių, dabar pateikiamų (preliminarių) duomenų pristatytų kontekstui suvokti reikalingą papildomą informaciją apie aktualias kultūrines idejjas. Tokie „subjektyvūs“ kolektyvinès sąmonès lygmens sociokultūriškai reikšmingi duomenys prisidètų ịprasminant dabar objektų aprašuose vyraujančius užsklęstus objekto būtyje „objektinius“ duomenis. Tokia informacinè sistema, kaip savotiškas "objektinio paso“ ir „subjektinio paso“ derinys, siekiant geresnio apžvelgiamumo, galètų būti pateikiama kaip dinaminis semantinis žodynas - tezauras.

\section{Literatūra}

Andersen, B. 1999. Isivaizduojamos bendruomenès. Apmastymai apie nacionalizmo kilmę ir plitima. Vilnius: Baltos lankos. $245 \mathrm{p}$.

André, E. F. 1879a. L’art des jardins: traité général de la composition des parcs et jardins. Paris: G. Masson. 888 p.

Andre, E. F. 1879b. Apie uolas [interaktyvus] (vertèjas nenurodytas), [žiūrèta $2010 \mathrm{~m}$. spalio $17 \mathrm{~d}$.]. Prieiga per internetą: $<\mathrm{http}: / /$ manoparkas.lt/Lentvaris/index.html $>$.

Andre, E. F. 1879c. Gèlès [interaktyvus] (vertèjas nenurodytas) [žiūrèta 2010 m. spalio 15 d.]. Prieiga per internetą: <http:// www.manoparkas.lt/Andre/Sodu_menas_sk_Geles.pdf >.

André-Olivier, F.; Deveikienė, V.; Deveikis, S. 2006. Eduardo André kūrybos paveldas Vilniaus miesto plètros kontekste, Urbanistika ir architektūra 30(1): 38-46.

Apžvalgine ir situacijos įvertinimo misija. 2001. Parkai ir sodai/ Lietuvos kraštovaizdžiai [interaktyvus]. Europos Kultūros kelių institutas, Europos sodų ir kraštovaizdžio kultūros centras, Lietuvos kultūros vertybių apsaugos departamentas. $2001 \mathrm{~m}$. birželio $8-13$ d. [žiūrèta $2010 \mathrm{~m}$. spalio $17 \mathrm{~d}$.]. Prieiga per internetą: <http://www.kpd.lt/lt/node/915>.

Belting, H.; Dilly, H.; Kemp, W.; Sauerlander, W.; Wranke, M. 2002. Meno istorijos iqvadas. Vilnius: Alma littera. 376 p.

Bialostocki, J. 1982. Symbole i obrazy. Tom I. Warszawa: Panstwowe Wydawnictwo Naukowe. 506 s. 
Biedermann, H. 2002. Naujasis simbolių žodynas. Vilnius: Mintis. 543 p.

Brunzaitè-Baltrus, E. 1997. Žaliojo grožio principai, Arkitektas 2-3: 82-85.

Deveikiene, V.; Deveikis, S. 2000. Lentvario dvaro sodyba parkotyros ir parkotvarkos žvilgsniu, Žemetvarka ir melioracija 2(102): 72-77.

Deveikiene, V.; Deveikis, S. 2010. Lentvario dvaro parko istorinès ir menines raidos apybraiža. Vilnius: Lietuvos turto vertintojų asociacija. $96 \mathrm{p}$.

Deveikis, S. 2010. Lentvario parkas kaip pittoresque išraiškos erdvè, iš Plenero „Lentvario parko slépiniai“, skirto parku kūrejjui ir teoretikui E. F. André. Seminaras Lentvaryje, 2010-07-16 [interaktyvus] [žiūrèta $2010 \mathrm{~m}$. lapkričio 25 d.]. Prieiga per internetą: $<$ http://www.slideshare.net/tag/steponas-deveikis>.

Dickie, G. 2005. Aesthetics, in The Routledge History of Philosophy. Vol X. Philosophy of Meaning, Knowledge and Value in the Twentieth Century. Ed. J. V. Canfield. London and New York: Routledge. 325 p.

Dobkevičius, K. 2004. Tikimasi restauruoti E. Andrè projektuotus parkus, XXI amžius [interaktyvus] 63(1266), $2004 \mathrm{~m}$. rugpjūčio 25 d. [žiūrèta $2010 \mathrm{~m}$. lapkričio 25 d.]. Prieiga per internetą: $<$ http://www.xxiamzius.lt/ numeriai/2004/08/25/zvil_02.html $>$.

Eaton, M. M. 2009. Vidine, neišvestinè estetinių savybių prigimtis, iš Estetika - XX amžius: problemos, teorinés kryptys, konfrontacijos: antologija. I tomas. Sud. A. Katalynas. Vilnius: Mintis, 73-77.

Athanasius Kircher. The Last Man Who Knew Everything. 2004. P. Findlen (Ed.). New York and London: Routledge. 465 p.

Fontana dei Quattro Fiumi. 2005. Fountain of the four rivers by Gianlorenzo Bernini in piazza Navona in Rome, Italy [interaktyvus]. Picture by Stefan Bauer 20050903 [žiūrèta $2010 \mathrm{~m}$. spalio 17 d.]. Prieiga per internetą $<$ http://en.wikipedia.org/wiki/File:Vierstroemebrunnen_ Piazza_Navona_Rom.jpg >.

Groat, L.; Wang, D. 2002. Architectural Research Methods. New York: John Willey and Sons. 389 p.

Gurevičius, A. 1989. Viduramžiu kultūros kategorijos. Vilnius: Mintis. 290 p.

Jakovlevas-Mateckis, K. 2010. Sereikiškiu parkas: išlikimo drama [interaktyvus], [žiūrèta $2010 \mathrm{~m}$. spalio $20 \mathrm{~d}$.]. Prieiga per internetą: <http://www.bernardinai.lt/straipsnis/-/51464>.

Kvietkauskas, V. 1985. Tarptautiniu žodžiu žodynas. Vilnius: Vyriausioji enciklopedijų redakcija. 528 p.

Lentvario dvaro sodybos parkas. 1996. Kultūros vertybès aprašas. Objekto ịreg. Nr. MC22212, kultūros vertybès kodas G12K11. Kultūros paveldo centras. 19960721.

Lentvario parkas [interaktyvus]. 2010 [žiūrèta 2010 m. spalio 17 d.]. Prieiga per internetą: <http://manoparkas.lt/ Lentvaris/index.html>.

Levandauskas, V. 1989. Lentvario ansamblis vakar ir šiandien, Statyba ir architektūra 1(357): 22-23.

Levandauskas, V. 2000. Dvarų sodybos, iš Lietuvos architektūros istorija. T. 3. Nuo XIX a. antrojo dešimtmečio iki $1918 \mathrm{~m}$. Vilnius: Savastis, 342-408.

Lo Sardo. 2004. E. Kircher's Rome, in Athanasius Kircher. The Last Man Who Knew Everything. Ed. P. Findlen. New York and London: Routledge. 51-62.
Lotmanas, J.; Uspenskis, B. 2004. Mitas - vardas - kultūra, iš Lotmanas, J. Kultūros semiotika. Vilnius: Baltos lankos, 231-253.

Nekilnojamujų kultūros vertybiu vertinimo ir atrankos kriteriju aprašas. 2005. Patv. LR kultūros ministro $2005 \mathrm{~m}$. balandžio 15 d. ịsakymu Nr. IV-150.

Novickas, A. 2010. Atminties ịprasminimas miesto aikštèje: nuo paminklo iki patirčiu erdvès: mokomoji knyga. Vilnius: Technika. 89 p. doi:10.3846/1131-S

Petrušonis, V. 2002. Vietovès kultūrinio tapatumo subjektinis substratas, Urbanistika ir architektūra 26(1): 18-36.

Petrušonis, V. 2004. Introdukuotieji kultūriniai klodai Kauno architektūroje, Urbanistika ir architektūra 27(3, priedas): 57-62.

Petrušonis, V. 2006. Urbanistinių vertybių apsaugos metaloginis aspektas, iš Kultūros paveldas ir visuomene XXI a. nacionaliniai ir tarptautiniai aspektai. Vilnius: Vilniaus dailès akademijos leidykla, 95-108.

Petrušonis, V. 2008. New technologies and specificities of synthesis of art and science modes of cognition, in Architectural Inquiries: theories, methods and strategies in contemporary Nordic architectural research. Nordic-Baltic Conference. April 24-26, 2008. Publikation - Chalmers Tekniska Högskola, Institutionen för Arkitektur. Göteborg [CD]. 9 p.

Stučkaitè, D. 2000. Lentvario dvaro ansamblis ir jo kürejjai. Menotyros bakalauro darbas. Vad. N. Tolvaišienè. Kaunas: VDU. 67 p.

Šetkus, K. 2002. Lentvario dvaro sodybos architektūriné analizé ir reikšmè. Menotyros bakalauro darbas. Vad. V. Stauskas. Kaunas: VDU. 53 p.

Tauras, A. 1989. Mūsu parkai. Vilnius: Mokslas, 257 p.

Аверинцев, С. 1987. От берегов Босфора до берегов Евфрата: литературное творчество сирийцев, коптов и ромеев в I тысячелетии н. э., в кн. От берегов Босфора до берегов Евфрата. Москва: Наука, 5-52.

Бахтин, М. М. 1986. Эстетика словесного творчества. 2-е изд. Москва: Искусство. 445 с.

Двориово-парковый комплекс. Словарь по естественным наукам. Глоссарий.py [interaktyvus]. 2010 [žiūrèta 2010 m. spalio 24 d.]. Prieiga per internetą: $<$ http://www. glossary.ru/cgi-bin/gl_sch2.cgi?REiuw.uiu-vgwqui: l!qusvrlqx: >.

Топоров, В. Н. 1973. О космологических истоках раннеисторических описаний, Труды по знаковым системам 6: 106-150.

Топоров, В. Н. 1983. Пространство и текст, в кн. Текст: семантика и структура. Москва: Наука, 227-284.

Ямпольский, М. Б. 1987. К символике водопада, Труды по знаковым системам 21: 26-41.

\section{ROLE OF CULTURAL CONTEXT IN EVALUATING ARCHITECTURAL COMPLEX}

\section{Petrušonis}

Abstract. Generally architectural complexes are evaluated and interpreted on the basis of denotative knowledge without taking into account additional background information regarding a broader cultural context. The value of objects 
is defined superficially operating with accidental historical, cultural and aesthetic information. Usually final evaluation is presented summing up all the revealed qualities. However, this summing approach has an essential disadvantage because it neglects the recursive character of perception and comprehension. In such a situation some external contextual knowledge that corresponds with archetypical information has to be added. Such an information points up holistic aspect of mental representations of certain architectural complexes. Thanks to accepting controversial stimulants the connotations that are very important for a deeper understanding of essential features and final qualification of a complex are introduced. The process of understanding has resemblance with solving of a riddle, finding the key of enigma. Such a process is based on the so-called aesthetic comprehension rather than on logic deduction. In order to enable the process of comprehension additional cultural information has to be revealed in the moment of evaluating decision act. These measures enable to take into account a broader cultural context. The best prototype of the structure for presenting such an additional information is the model of a dynamic semantic dictionary - Thesaurus.
The paper is based on semantic analysis of Lentvaris Manor Park ensemble as a complex of cultural heritage importance. The mechanism, how a broader relevant context represented in an additional text (as a fragment of Thesaurus) is helpful to define the proper value of complex objects, is explained.

Keywords: evaluation of architectural complex, conceptual interpretation of architecture, cultural context, psychological background of evaluation process, semantic features of Lentvaris Manor Park.

\section{VYTAUTAS PETRUŠONIS}

Dr, Assoc. Prof., Dept of Fundamentals and Theory of Architecture, Vilnius Gediminas Technical University (VGTU),

Pylimo g. 26/Traku g. 1, 01132 Vilnius, Lithuania.

E-mail:vytas_petr@yahoo.com.

Doctor of the Humanities (architecture), VGTU, 2005. Research interests: respect for locus cultural identity, structural and typological features of architectural objects, metacritical analysis of architectural activity. 